interioryzatsii zmistu profesiinoi pidhotovky maibutnikh filolohiv: teoriia i praktyka [Strategy of internalization of the contents of the professional training of future philologists: theory and practice]. Monograph. (Ed.). prof. O. V. Malikhin. Part 2. Kyiv, pp.141-155. [in Ukrainian].

8. Sinyagovska, I. Yu. (2015). Problema interiorizatsii znan u psikhologo-pedagogichniy nautsi [The problem of internalization of knowledge in psychological and pedagogical science]. Pedagogy of higher and secondary schools. Vol. 45, pp. 292298. [in Ukrainian].

9. Filosofskyi entsyklopedychnyi slovnyk (2002). [Philosophical Encyclopedic Dictionary]. V. (Ed.).I. Shynkaruk et al.; Kyiv, p.253. [in Ukrainian].
10. Babenko, O. V. (2018). Strategies of internalization in the process of teaching linguistic studies. Zbiyr artykuiyw naukowych ["Science, Research, development. Pedagogy"]. No.11, Warszawa: Diamond trading tour, pp.25-28.[in English].

11. Lantolf, J. P. (2008). Sociocultural theory and the teaching of second languages. London: Equinox Publishing.[in English].

12. Shabani, K. (2016). Applications of Vygotsky's sociocultural approach for teachers' professional development. Cogent Education, 3(1). [in English].

13. Walqui, A. (2006). Scaffolding instruction for English language learners: A conceptual framework. International Journal of Bilingual Education and Bilingualism, 9, pp.159-180. [in English].

Стаття надійшла до редакції ..2019

УДК $378.3: 811.246$

DOI:

Галина Задільська, кандидат філологічних наук, доиент кафедри порівняльної педагогіки та методики викладання іноземних мов Дрогобицького державного педагогічного університету імені Івана Франка

\title{
КОГНІТИВНО-КОМУНІКАТИВНИЙ ПІДХІД ДО НАВЧАННЯ МОНОЛОГУ ТА ДІАЛОГУ МОВЛЕННЯ СТУДЕНТІВ-ФІЛОЛОГІВ ЗВО
}

У статті висвітлено особливості реалізації когнітивно-комунікативноїметодики навчання студентівфілологів $3 В О$ монологічного та діалогічного мовлення. Розглядаються особливості застосування сучасних методів навчання монологічного та діалогічного мовлення, як невід'ємної складової професійної компетентності майбутніх вчителів, за допомогою адекватної організації навчальних занять і запровадження інтерактивних видів аудиторних робіт; обтрунтовується доцільність і необхідність розвитку вмінь і навичок іншомовного спілкування у студентів-філологів $3 B О$ за сучасних умов інтеграції в міжнародний освітній nростір.

Ключові слова: сучасні педагогічні технологї; когнітивно-комунікативна методика; когнітивні методи навчання; мовна система; монологічне та діалогічне мовлення; студенти-філологи 3 ВО.

Jim. 10.

Halyna Zadilska, Ph.D.(Philology), Associate Professor of the Comparative Pedagogics and Methodology of Foreign Languages Teaching Department, Drohobych Ivan Franko State Pedagogical University

\section{COGNITIVE-COMMUNICATIVE APPROACH TO MONOLOGUE AND DIALOGUE SKILLS TRAINING OF UNIVERSITY STUDENTS OF LINGUISTIC DEPARTMENTS}

The article deals with the peculiarities of cognitive-communicative methods of teaching monologue and dialogue speech, with the implementation of new modern techniques of monologue and dialogue speech in the training of university students of linguistic departments as an important component of their professional competence as future teachers which is derived with the help of appropriate organization of studies and use of interactive methods; the grounding of the suitability and necessity of foreign language communication of university students of linguistic departments in the modern conditions of international educational integration is given. The analysis of cognitive-communicative approach in the light of its two basic methods - the cognitive and communicative has been done. Definition of communicative and cognitive methods is given. The opportunity of unification of cognitive and communicative knowledge systems for the solution of the practical problem - monologue and dialogue speech teaching as a thinking concept and a functional unit is considered in the article. In teaching monologue it is mentioned the importance of forming both-unprepaired and prepaired monologue speech. In teaching dialogue speech the attention has been paid to instructional and untechnical technologies among which verbal, non-verbal 


\section{КОГНІТИВНО-КОМУНІКАТИВНИЙ ПІДХІД ДОНАВЧАННЯ МОНОЛОГУ ТА ДІАЛОГУ МОВЛЕННЯ СТУДЕНТІВ-ФІЛОЛОГІВ ЗВО}

(visual), verbal-visual, audio-visual and audio materials are considered. Four basic types of dialogues in spoken interaction have been worked out. Such modern techniques of dialogue speech are distinguished - Webquest and Case Study methods, imitating interactive pedagogical technologies mainly communicative directed and roleplayed methods. The article proves that modern pedagogical technologies promote the development of students' communicative skills and creativity.

Keywords: modern pedagogical technologies; cognitive-communicative approach; cognitive training methods; language system; university students of linguistic departments.

П остановка проблеми у загальному вигляді та її зв'язок з важливими науковими чи практичними завданнями. Оскільки XXI століття - це час науково-технічного прогресу 3 інтенсивним використанням надрозвиненого інтелекту, що, своєю чергою, полегшує процес сприйняття та засвоєння студентами іншомовного матеріалу, перед викладачем закладів вищої освіти постає завдання послуговуватись різними видами медійної техніки та програмами, які її обслуговують, новими педагогічними методами i технологіями для досягнення комунікативної компетентності студентів-філологів. Адже підготовка студентів як майбутніх кваліфікованих вчителів іноземної мови та вироблення у них професійних навиків монологічного та діалогічного мовлення дозволять майбутнім фахівцям суттєво розширити міжнародні контакти із закордонними колегами-педагогами та їхніми студентами, що, звичайно, є запорукою організації навчання у співпраці та відбору автентичного навчального матеріалу 3 перманентним спілкуванням 3 носіями мови.

Ми виділяємо когнітивно-комунікативний підхід (далі - ККП) до навчання монологу та діалогу тому, що до базових принципів цього підходу належать: принцип цілісного сприйняття інформації, принцип взаємопов'язаного навчання видів мовленнєвої діяльності, принцип системності $[3,63]$. Таким чином, питання про когнітивно-комунікативне навчання англомовної компетенції монологічного та діалогічного мовлення студентів-філологів ЗВО є надзвичайно актуальним.

Аналіз основних досліджень і публікацій. Попри той факт, що методику навчання монологічного та діалогічного мовлення розробляли у різний час багато вчених $[2 ; 4 ; 7 ; 9$; 10], проте досліджуване питання не може вважатися вирішеним у методичній науці, оскільки потребує розгляду з огляду на ККП.

ККП до навчання мови є одним із найпріорітетніших у реалізації стандарту мовної освіти. Слідом за А. Щепіловою, в навчанні іноземної мови ККП передбачає оптимальну організацію пізнавальних дій студентів відповідно 3 природною пізнавальною поведінкою людини.
Авторка, посилаючись на Л. Виготського [1, 126], зазначає, що необхідність застосування ККП зумовлюється наступним фактором: мова $\epsilon$ водночас інструментом спілкування та інструментом пізнання дійсності. Цей постулат узгоджується 3 загальним розумінням суті комунікативної компетенції людини як знання, уявлення про мову і здібність до мовленнєвих дій та умінь в комунікативній сфері. У сучасній методиці викладання іноземних мов процес формування адекватного уявлення про лінгвістичне явище та розвиток умінь його використовувати в реальній комунікації сприймаються як рівнозначно важливі. Власне тому формування уявлення про мовне явище відбувається шляхом використання індивідуального набору пізнавальних прийомів, або стратегій: метакогнітивних (планування, вибіркова увага, самокорекція, самооцінка); когнітивних (повторення, класифікація, здогадка, перенесення, дедукція і індукція і ін.); соціальних (співробітництво); афективних (контроль емоцій) на кожному етапі пізнання. Завдання викладача полягає в тому, щоб створити оптимальні умови для тренування студентів у використанні вищезазначених стратегій та надати їм можливість використовувати наявні знання та вміння $[8,6]$.

Таким чином, метою статті $є$ розкриття переваг реалізації когнітивно-комунікативної методики навчання монологу та діалогу мовлення студентів-філологів ЗВО з використанням сучасних педагогічних технологій.

Виклад основного матеріалу. Монологічне мовлення у психологічному та лінгвістичному відношенні - складна форма усного мовлення, оскільки це мовлення однієї особи до слухачів, воно більш розгорнуте, вимагає зосередженості пам'яті й уваги до змісту і форми мовлення. Монологічне мовлення спирається на мислення, яке логічно більш послідовне, ніж у процесі діалогу. Монолог не підтримується ситуацією або запитаннями на відміну від діалогу, він здебільшого адресований не одній людині, а багатьом. Монологічне мовлення, як мовлення однієї особи, потребує розгорнутості, повноти, чіткості і взаємозв' язку окремих частин розповіді, вміння мовця зосередити свою думку на 
головному, не захоплюватися деталями, водночас говорити емоційно, жваво, образно [5].

На практичних заняттях з англійської мови одним із базових прийомів у навчанні монологічного мовлення $є$ переказ тексту: спершу словами автора, згодом - переказ його власними словами, що на нашу думку є недоліком викладання іноземної мови у закладах вищої освіти. 3 власних спостережень можемо стверджувати, що не можна обмежуватися тільки переказом тексту. Якщо дотримуватися такого підходу до навчання, то у студентів не сформуються найпростіші навички непідготовленого мовлення. Загалом використання штучного матеріалу не веде до створення життєвих умов та ситуацій спілкування. Натомість стимулювання використання вивченого матеріалу в нових мовних ситуаціях розглядається нами як основа у навчанні монологічного мовлення.

На нашу думку, необхідно формувати вміння як непідготовленого, так і підготовленого монологічного мовлення. Зазначимо, що доповіді, презентації, заздалегідь заплановані виступи перед аудиторією - це повністю підготовлений монолог, проте така форма роботи повинна здійснюватися 3 використанням новітніх інтерактивних педагогічних технологій: міжнародні та всеукраїнські Інтернет-конференції, спільні проекти тощо.

Непідготовлений за змістом, формою та часом монолог розвиває базові навички та вміння, оскільки власне воно $є$ найбільш природним та базовим для усного спілкування взагалі. Викладач постійно створюючи ситуацію спілкування i послуговуючись постулатами ККП, повинен налаштовувати студентів на обговорення тих тем, що відповідають віку та інтересам студентів, їх рівню розвитку, набутих мовленнєвих умінь i навичок, засобів, які функціонують в реальному житті.

Перейдемо до розгляду діалогічного мовлення, яке на відміну від монологічного, неможливо спланувати заздалегідь. Адже обмін репліками відбувається досить швидко, і реакція вимагає нормального темпу мовлення, що, своєю чергою, зумовлює спонтанність, непідготовленість мовленнєвих дій, потребує досить високого ступеня автоматизму та готовності до використання мовного матеріалу.

На нашу думку традиційна методика при навчанні діалогічного мовлення, аналогічно як і монологічного мовлення, тісно переплітається 3 новітніми технологіями, які викладач комплексно впроваджує у навчальний процес на практичних заняттях. Так, засоби навчання для формування іншомовної комунікативної компетенції у діалогічному мовленні різноманітні і іх перелік може стати невичерпним залежно від майстерності викладача, цілей та етапів навчання. Ми ж, слідом за В.В. Черниш, виділяємо нетехнічні та технічні. Нетехнічні засоби поділяються на:

1) вербальні опори (мікродіалог, діалог-зразок, мікродіалог-підстановча таблиця, структурномовленнєва схема, функціональна схема мікродіалогу, об'єднані між собою функціональна і структурно-мовленнєва схема діалогу);

2) невербальні (зображальні) опори (сюжетний малюнок, серія малюнків, фотографій, листівок, різноманітні плани будинків, будівель, карта погоди);

3) вербально-зображальні опори (схематичний план міста, будівлі тощо).

Технічні засоби поділяються на:

1) аудіо-візуальні (відеозапис: відеофільм, відеосюжет, мультиплікаційний фільм, навчальний фільм тощо),

2) аудитивні (аудіо запис: фоновправи, радіопередачі тощо) $[7,16]$.

Ми, як правило, використовуємо на практичних заняттях для формування у майбутніх учителів англійської мови компетенції у діалогічному мовленні такі чотири базові типи діалогів: діалог-розпитування, діалог-домовленість, діалог-обмін враженнями/ думками, діалог-обговорення/дискусія.

Додамо, що ігрові методи надають відчуття реальності навчальної гри, що, своєю чергою, підвищує серйозність запропонованої ситуації та мовленнєву активність студентів під час обміну думками та поглядами у контексті обговорення та вирішення певної проблеми. 3 метою активного засвоєння знань необхідно перетворити заучування матеріалу на захопливу гру [6].

У практичній діяльності ефективними технологіями навчання діалогу вважаємо активні методи: проблемно-діяльнісне навчання (Webquest), навчання у співпраці, контекстне навчання, метод проектних технологій, ігрові технології та технологію вивчення окремих професійних ситуацій (Case Study).

Висновки і перспективи подальших розвідок у даному напрямку. Монологічне та діалогічне мовлення студентів ЗВО формується через особисту діяльність студентів залежно від їхніх індивідуальних і творчих здібностей. Вони ж і є базовими суб'єктами навчання та володіють когнітивними і метакогнітивними стратегіями та прийомами оволодіння мовою й іншомовним спілкуванням, усвідомлюючи свої успіхи і невдачі. Кожне практичне заняття з іноземної мови розглядається як діяльність спілкування, власне 
відмову від домінування на уроках формальних мовних вправ на користь діяльнісно й інтелектуально-орієнтованих завдань, які дають змогу вивчати іноземну мову як основний засіб міжкультурного спілкування.

Перспективи подальших досліджень вбачаємо у подальших теоретичних дослідженнях та практичних розробках сучасних педагогічних технологій навчання студентів-філологів 3ВО англомовного монологу та діалогу, створенні детальної класифікації засобів навчання монологічного та діалогічного мовлення та розробці відповідних опор для студентівбакалаврів та студентів-магістрів.

\section{ЛІТЕРАТУРА}

1. Выготский Л. С. Мышление и речь. Москва, 1999. $254 \mathrm{c}$.

2. Кіршова О.В. Професійно орієнтовані завдання у підготовці майбутніх викладачів до навчання студентів монологічного мовлення. Педагогічні науки : зб. наук. працьь. Херсон, 2011. № 57. С. 277-283.

3. Клименко М. В. Когнітивний підхід до навчання спілкування англійською мовою. Англійська мова та література. 2017. № 7-8. С. 63.

4. Матвійчук Т.А. Фрагмент практичного аняття німецької мови з формування у студентів другого курсу компетентності в діалогічному мовленні 3 використанням соціокультурного колажу. Іноземні мови. 2017. № 3(91). С. 47 - 51.

5. Селіванова О. Сучасна лінгвістика : термінологічна енциклопедія. Полтава, 2006. 716 с.

6. Столяренко О.В.Виховання культуритолерантних взаємин у студентської молоді. Навчально-методичний посібник. Вінниця, 2014.248 c.

7. Черниш В.В. Засоби формування іншомовної компетенції у діалогічному мовленні. Іноземні мови. 2011.№ 3 (67). С. 15 - 22.

8. Щепилова А.В. Когнитивный принцип в обучении второму иностранному языку: к вопросу о теоретическом основании. 2003. №2. С. 4-11.

9. Ярошенко О. В. Кейс-метод як сучасна технологія формування професійно орієнтованої компетентності в діалогічному мовленні майбутніх викладачів англійської мови. Іноземні мови. 2014. № 2(78). С. 39 - 44.

10. Maley A., Drama techniques: a resource book of communication activities for language teachers. Third edition / Alan Maley, Alan Duff. Cambridge: Cambridge University Press, 2005. 246 p.

\section{REFERENCES}

1. Vyhotskyi, L. S. (1999). Myshlyeniye i ryech [Thinking and Speech]. Moscov, 254 p. [in Russian].
2. Kirshova, O. V. (2011). Profesiino oriyentovani zavdannya u pidhotvtsi maibutnikh vukladachiv do navchannya studentiv monolohichnoho movlennya [Professionaly oriented tasks in future teachers command in teaching students onoloue speech]. Pedagogical Sciences: a Collection of Sciences. works. Kherson, No.57, pp. 277-283. [in Ukrainian].

3. Klymenko, M. V. (2017). Kohnityvnyi pidhid do navchannya spilkuvannya anhliiskoyu movoyu [Cognitive approach to English speaking teaching]. English language and literature, No. 7-8, p. 63. [in Ukrainian].

4. Matviichuk, T. A. (2017). Frahment praktychnoho zanyattya nimetskoi movy $\mathrm{z}$ formuvannya $u$ studentiv druhoho kursu kompetentnosti u dialohichnomu movlenni $\mathrm{z}$ vukrystannyam sotsiokulturnoho kolazhu [The fragments of the German language lesson for developing of second-year students' spoken interaction skills using a socio-cultural collage]. Foreign languages, 3(91), pp. 47 - 51. [in Ukrainian].

5. Selivanova, O. (2006). Suchasna linhvistuka: terminolohichna entsyklopediya [Modern Linguistics : Terminological Encyclopedia]. Poltava, 716 p. [in Ukrainian].

6. Stolyarenko, O. V. (2014). Vychovannya kultury tolerantnych vzayemyn u studentskoyi molodi [Training of tolerant mutual relation culture to the students]. Tutorial, Vinnytsya, 248 p. [in Ukrainian].

7. Chernysh, V. V. (2011). Zasoby formuvannya inshomovnoyi kompetentsiyi u dialohichnomu movlenni [Means of forming foreign competence in dialogue speech]. Foreign languages,3(67), pp. 15 -22 . [in Ukrainian].

8. Shchepilova, A. V. (2003). Kohnityvnyi printsyp v obucheniyi vtoromu inostrannomu yazyky: k voprosu o teoreticheskom osnovaniyi [Cognitive approach in second foreign language teaching: theoretical basis question]. No.2, pp. 4-11. [in Russian].

9. Iaroshenko, O. V. (2014). Keis-metod yak suchasna technolohiya fomuvannya profesiino oriyentovanoyi kompetentnosti $\mathrm{v}$ dialohichnomu movlenni maibutnikh vykladachiv anhliiskoyi movy [The case-study as a modern technique in developing professionally oriented interactive communication of the future English teachers]. Foreign languages, 2(78), pp. 39 - 44. [in Ukrainian].

10. Maley, A. \& Duff, A. (2005). Drama techniques: a resource book of communication activities for language teachers. Third edition, Cambridge: Cambridge University Press, 246 p. [in English].

Стаття надійшла до редакції 02.07.2019 